УДК 636. 087.7+636.2.084.1

DOI 10.36461/NP.2020.54.1.017

\title{
ЭФФЕКТИВНОСТЬ ПРИМЕНЕНИЯ КОРМОВОЙ ДОБАВКИ НА ОСНОВЕ ДЕФЕКАТА САХАРНОГО ПРОИЗВОДСТВА В КОРМЛЕНИИ ТЕЛЯТ В ЗИМНИЙ ПЕРИОД ВЫРАЩИВАНИЯ
}

Н. Н. Кердяшов, доктор биол. наук, профрессор; А. И. Дарьин, доктор с.-х. наук, профрессор

Федеральное государственное бюджетное образовательное учреждение высшего образования «Пензенский государственный аграрный университет»,

Россия, г. Пенза, т. 8-9061589996, e-mail: nikolai1302@mail. ru

\section{А. В. Овчинников, доктор с.-х. наук, профрессор}

Федеральное государственное бюджетное образовательное учреждение высшего образования «Российский государственный аграрный университет МСХА имени К. А. Тимирязева», Россия, г. Москва

Поволжье относится к биогеохимическим провинциям, дефицитным по содержанию фосфора, серы, натрия, цинка, йода, меди, кобальта. Дефекат сахарного производства содержит кальций, фосфор и ещё целый ряд ценных элементов питания. Применение дефеката и кормовых добавок на его основе взамен мела кормового способствует сохранению окружающей среды от загрязнения отходами производства сахара. В 1 кг новой кормовой добавки из дефеката сахарного производства, ванилина и препарата витамина Д содержалось: кальция - 285 г, фосффора - 12,5 г, сырого протеина - 61,5 г, сахара - 25 г, железа - 3,9 г, меди - 4,2 мг, марганца - 86,3 мг, цинка - 7,9 мг, кобальта - 0,11 мг, витамина Д - 55000 ME. Поедаемость телятами новой кормовой добавки на 31,6-61,1 \% выше по сравнению с кормовым мелом. Включение вволю в рационы телят данной кормовой добавки в зимний период выращивания при отсутствии премиксов достоверно улучшает основные зоотехнические показатели молодняка по сравнению с применением вволю кормового мела: живую массу - на 3,1-3,8 \%, среднесуточный прирост живой массы - на 10,3-15,4 \%, абсолютный прирост живой массы - на 10,3-15,2 \%; затраты кормов на 1 кг прироста живой массы телят ниже контроля на 9,4-13,2 \%. Применение исследуемой кормовой добавки является экономически выгодным, так как при этом себестоимость 1 кг прироста живой массы телят ниже на 18,81-19,33 руб.

Ключевые слова: дефрекат сахарного производства, ванилин, препарат витамина Д, мел кормовой, телята, зоотехнические показатели.

\section{Введение}

Поволжье относится к биогеохимическим провинциям, дефицитным по содержанию фросфора, серы, натрия, цинка, йода, меди, кобальта [1].

В связи с этим, использование различных доступных нетрадиционных кормовых добавок, улучшающих качество рационов, оказывающих положительное влияние на фризиологическое состояние организма, позволяющих получать высококачественную, экономически выгодную, конкурентоспособную продукцию, является актуальным.

Практический опыт, накопленный в России и других странах, свидетельствует о высокой эфрфективности применения местных источников кормовых добавок [2, 6-8, $10,11]$, побочных продуктов пищевого происхождения в сельском хозяйстве $[3,6-8$, 16-21].

Так, дефекат (фильтрационный осадок) сахарного производства известен как де- шёвый (стоит в несколько раз меньше) заменитель кормового мела в рационах животных и доступный, эффективный сорбент [3, 5-9, 12, 16, 17]. Использование дефеката сахарной промышленности в свеклосеющих регионах в качестве источника минеральных элементов способствует сохранению окружающей среды от загрязнения отходами производства сахара [6-8].

Цель работы - разработка, зоотехническая и экономическая оценка целесообразности применения вволю при отсутствии премиксов в рационе телят новой кормовой добавки из дефеката сахарного производства, ванилина и препарата витамина Д вместо скармливания вволю кормового мела.

Для достижения указанной цели были поставлены следующие задачи:

1) разработать кормовую добавку из дефеката, витамина Д и ванилина для телят;

2) установить поедаемость кормовой 
добавки и мела кормового при скармливании их телятам вволю;

3) определить влияние исследуемой кормовой добавки на динамику основных зоотехнических показателей;

4) дать экономическое обоснование эффективности использования кормовой добавки в кормлении телят.

\section{Методы и материалы}

Первый научно-хозяйственный опыт по принципу сбалансированных групп (с учётом породы, живой массы, возраста, происхождения) выполнен на базе АO «Учхоз «Рамзай» ПГСХА» Мокшанского района на телятах чёрно-пёстрой голштинизированной породы в возрасте от двух до четырех месяцев. Второй научнохозяйственный опыт (с учётом породы, живой массы, возраста, происхождения) проведён на базе АО «Учхоз «Рамзай» ПГСХА» на телятах в возрасте от 5-6 до 7-8 месяцев (табл. 1).

Изучалось влияние на энергию роста, затраты кормов, сохранность поголовья скармливания новой кормовой добавки (десрекат сахарного производства + ванилин + витамин Д).

По содержанию кальция дефекат незначительно уступает мелу кормовому и известняку. Но кроме кальция он содержит фосффор и ещё целый ряд ценных элементов питания, которые в меле кормовом и известняке отсутствуют [3, 6-8].

Запасы дефеката на трех сахарных заводах Пензенской области составляют около двух миллионов тонн. Его стоимость в несколько раз дешевле кормового мела, который в Пензенской области не добывается, а завозится из других регионов страны.

Дефекат сахарного производства перед использованием высушивали и измельчали.

Кормовая добавка из дефеката сахарного производства, ванилина и препарата витамина Д, как и мел кормовой, скармли-

вались телятам вволю из отдельных кормушек. Ванилин включался для улучшения аппетита молодняка, увеличения поедаемости дефеката. Препарат витамина Д применяли для устранения его существенного дефицита в рационе и повышения при этом усвоения кальция и фоссрора.

Остатки мела кормового (у контрольной группы) и кормовой добавки (дефекат + ванилин + препарат витамина Д - у животных опытной группы) взвешивали через каждую неделю эксперимента и засыпали в кормушки новые порции. По разности массы этих добавок в начале и конце недели определялась их поедаемость.

В течение первого научно-хозяйственного опыта в зависимости от возраста и живой массы животные контрольной и опытной групп получали зимние рационы из сена люцернового, силоса вико-овсяного, жмыха подсолнечного, дерти овса, молока цельного и соли поваренной.

Зимние рационы телят второго научнохозяйственного опыта содержали сено кострецовое, сенаж вико-овсяный, дерть овса и гороха, жмых подсолнечный, патоку, динатрийфосфрат и соль поваренную.

Все рационы, в основном, соответствовали рекомендуемым детализированным нормам PACXH [4], предназначенные для выращивания коров с живой массой 550600 кг.

Перед постановкой на опыт (в первом научно-хозяйственном опыте в возрасте двух месяцев, во втором научно-хозяйственном опыте в 5-6 месячном возрасте), а также в конце эксперимента (соответственно в четырех месячном возрасте и в возрасте 7-8 месяцев) проводили взвешивание подопытных животных для определения фактической живой массы и её прироста по методике, описанной Овсянниковым А. И. (1976).

Достоверность различий групповых средних определяли по t-критерию [15].

Таблица 1

Схема собственных исследований

\begin{tabular}{|l|c|c|c|l|}
\hline \multicolumn{1}{|c|}{ Группа } & $\begin{array}{c}\text { Коли- } \\
\text { чество } \\
\text { голов }\end{array}$ & $\begin{array}{c}\text { Возраст при } \\
\text { постановке, } \\
\text { мес. }\end{array}$ & $\begin{array}{c}\text { Продолжи- } \\
\text { тельность, } \\
\text { дни }\end{array}$ & Характеристика кормления \\
\hline \multicolumn{5}{|c|}{ Первый научно-хозяйственный опыт } \\
\hline Контроль & 15 & 2 & 60 & ОР + мел кормовой вволю \\
\hline Опытная & 15 & 2 & 60 & $\begin{array}{l}\text { ОР + дефекат сахарного производства } \\
\text { с ванилином и витамином Д вволю }\end{array}$ \\
\hline Второй научно-хозяйственный опыт & 50 & ОР + мел кормовой вволю \\
\hline Контроль & 14 & $5-6$ & 60 & $\begin{array}{l}\text { ОР + дефекат сахарного производства } \\
\text { с ванилином и витамином Д вволю }\end{array}$ \\
\hline Опытная & 14 & $5-6$ & 60 &
\end{tabular}

*Основной рацион. 
Основные зоотехнические показатели

первого научно-хозяйственного опыта на телятах, $M \pm m$

\begin{tabular}{|c|c|c|c|}
\hline \multirow{2}{*}{$\begin{array}{l}\text { Группа } \\
(\mathrm{n}=15)\end{array}$} & \multirow{2}{*}{ Показатель } & \multicolumn{2}{|c|}{ Возраст, мес. } \\
\hline & & 2 & 4 \\
\hline \multirow{4}{*}{$\begin{array}{l}\text { Кон- } \\
\text { трольная }\end{array}$} & Живая масса, кг & $60,15 \pm 0,87$ & $99,69 \pm 0,78$ \\
\hline & Абсолютный прирост, г & - & $39,54 \pm 0,76$ \\
\hline & Среднесуточный прирост, г & - & $659,0 \pm 15,8$ \\
\hline & Затраты кормов на 1 кг прироста, ЭКЕ & - & 4,25 \\
\hline \multirow{4}{*}{ Опытная } & Живая масса, кг & $59,90 \pm 0,91$ & $103,52 \pm 0,89^{*}$ \\
\hline & Абсолютный прирост, г & - & $43,62 \pm 0,85^{\star *}$ \\
\hline & Среднесуточный прирост, г & - & $727,0 \pm 17,6^{\star \star}$ \\
\hline & Затраты кормов на 1 кг прироста, ЭКЕ & - & 3,85 \\
\hline
\end{tabular}

${ }^{*} p<0,05 ;{ }^{* *} p<0,01-$ достоверное различие с контролем.

\section{Результаты}

Главным управлением ветеринарии с государственной ветеринарной инспекцией дефекат рекомендован для применения в кормлении животных [14].

Нами разработана кормовая добавка, в 1 кг которой содержалось: кальция - 285 г, фосффора - 12,5 г, сырого протеина - 61,5 г, сахара - 25 г, железа - 3,9 г, меди - 4,2 мг, марганца - 86,3 мг, цинка - 7,9 мг, кобальта - 0,11 мг, витамина Д - 55000 МЕ.

Данная кормовая добавка содержит дефекат (отход пищевой промышленности), пригодный в пищу сельскохозяйственным животным в качестве источников кальция и других ценных элементов питания; витамин Д, способствующий усвоению кальция и фосфора из дефеката, и ванилин для улучшения аппетита, увеличения поедаемости этой добавки.

На протяжении первого научно-хозяйственного опыта в расчёте на одну голову в сутки телята контрольной группы съедали в среднем 15,2 г мела, а животные опытной группы - 20 г кормовой добавки из дефеката с ванилином и препаратом витамина Д (на 31,6 \% больше).

В первый месяц второго научно-хозяйственного эксперимента (в возрасте от 5-6 до 6-7 месяцев) в расчёте на одну голову в сутки телята контрольной группы съедали в среднем 19 г мела, а животные опытной группы - 32 г кормовой добавки из дефеката с ванилином и препаратом витамина Д (на 68,4 \% больше). Во второй месяц эксперимента (в возрасте от 6-7 до 7-8 месяцев) в расчёте на одну голову в сутки телята контрольной группы съедали в среднем 26 г мела, а животные опытной группы - 40 г исследуемой кормовой добавки (на 53,8 \% больше). В целом за период опыта поедаемость исследуемой кормовой добавки в среднем на $61,1 \%$ выше по сравнению с кормовым мелом.

В таблице 2 представлена динамика основных зоотехнических показателей телят в возрасте от двух до четырех месяцев (первый научно-хозяйственный опыт).

Из данной таблицы следует, что в начале эксперимента (в возрасте двух месяцев) живая масса телят не имела достоверного различия, но в четырех месячном возрасте молодняк опытной группы достоверно $(p<0,05)$ превышал контроль по живой массе на 3,83 кг или на 3,84\%; по абсолютному приросту на 4,08 кг или 10,3\% ( $<<0,01)$; по среднесуточному приросту на 68,0 г или 10,3\% (p<0,01). За период опыта затраты энергетических кормовых единиц на один кг прироста живой массы у опытной группы по отношению к контролю снизились на 9,4 \% (табл. 3).

Таблица 3

Основные зоотехнические показатели второго

научно-хозяйственного опыта на телятах, $M \pm m$

\begin{tabular}{|c|l|c|c|}
\hline \multirow{2}{*}{$\begin{array}{c}\text { Группа } \\
(\mathrm{n}=14)\end{array}$} & \multicolumn{1}{|c|}{ Показатель } & \multicolumn{2}{c|}{ Возраст, мес. } \\
\cline { 2 - 4 } & & $5-6$ & $7-8$ \\
\hline \multirow{3}{*}{$\begin{array}{l}\text { Кон- } \\
\text { трольная }\end{array}$} & Живая масса, кг & $132,78 \pm 1,67$ & $169,79 \pm 1,80$ \\
\cline { 2 - 4 } & Абсолютный прирост, г & - & $37,00 \pm 1,49$ \\
\cline { 2 - 4 } & Среднесуточный прирост, г & - & $616,7 \pm 24,8$ \\
\cline { 2 - 4 } & Затраты кормов на 1 кг прироста, ЭКЕ & $132,43 \pm 1,77$ & $175,07 \pm 1,73^{* *}$ \\
\hline \multirow{4}{*}{ Опытная } & Живая масса, кг & - & $42,64 \pm 1,62^{*}$ \\
\cline { 2 - 4 } & Абсолютный прирост, г & - & $710,6 \pm 27,0^{*}$ \\
\cline { 2 - 4 } & Зреднесуточный прирост, г & - & 4,80 \\
\cline { 2 - 4 } & Затраты кормов на 1 кг прироста, ЭКЕ & & \\
\hline
\end{tabular}

${ }^{*} p<0,05$; ${ }^{* *} p<0,01-$ достоверная разница с контролем. 
Сохранность молодняка за период эксперимента в контрольной и опытной группах была $100 \%$.

Динамика основных зоотехнических показателей телят в возрасте от 5-6 до 7-8месячного возраста (второй научно-хозяйственный опыт) приведена в таблице 3.

Из данных таблицы 3 следует, что в возрасте 7-8 месяцев молодняк опытной группы достоверно $(p<0,01)$ превышал контроль по живой массе на 5,28 кг или на 3,1\%; по абсолютному приросту на 5,64 кг или 15,2 \% (р $<0,05)$; по среднесуточному приросту на 93,9 г или $15,4 \%(p<0,05)$. За период опыта затраты энергетических кормовых единиц на один килограмм прироста живой массы у опытной группы по отношению к контролю снизились на $13,2 \%$ (табл. 3).

Сохранность телят за период эксперимента в контрольной и опытной группах была $100 \%$.

В результате первого научно-хозяйственного опыта установлено, что дополнительный доход на один кг прироста живой массы у телят опытной группы составил 19,33 руб.

Дополнительный доход на один кг прироста живой массы у телят опытной группы по данным второго научно-хозяйственного опыта оказался равным 18,81 руб.

\section{Заключение}

Таким образом, вследствие лучшей поедаемости телятами опытной группы скармливаемой вволю исследуемой кормовой добавки (за счёт ванилина и сахара в дефекате), наличию в ней витамина Д, а также других ценных элементов питания (благодаря дефекату сахарного производства), отсутствующих в меле кормовом, основные зоотехнические показатели (живая масса, абсолютный и среднесуточный приросты живой массы, затраты кормов на один кг прироста массы тела) у них оказались достоверно предпочтительнее, а себестоимость одного кг прироста живой массы ниже на 18,81-19,33 руб., по сравнению с контрольными животными, в рационе которых был вволю мел кормовой.

\section{Лumepamypa}

1. Гуткович, Я. Л. Продуктивность и обменные процессы в организме животных при разном уровне микроэлементарного питания / Я. Л. Гуткович // Корма и кормление сельскохозяйственных животных. - 1991.- № 4. - С. 4.

2. Дарьин, А. И. Использование эхинацеи пурпурной в кормлении кроссбредных свиней / А. И. Дарьин. - Пенза: РИО ПГСХА. - 2009. - 65 с.

3. Егоречева, О.Н. Эффективность использования фильтрационного осадка сахарного производства и экструдированной сои в рационах цыплят-бройлеров: автореферат диссертации на соискание ученой степени кандидата с.-х. наук. - Курск, 2002. - 20 с.

4. Калашников, А. П. Нормы и рационы кормления сельскохозяйственных животных: справочное пособие / А. П. Калашников, В. И. Фисенин, В.В. Щеглов и др. - Москва: Агропромиздат, 2003. -456 c.

5. Карунский, А. И. Отходы свеклосахарного производства в кормлении свиней и птицы / А. И. Карунский, Е. Ф. Крючкова, Н. И. Никильбурский // Зоотехния. - 1993. - № 9. - С. 15-18.

6. Кердяшов, Н. Н. Кормление молодняка животных с использованием комплексных кормовых добавок: монография / Н. Н. Кердяшов, А. И. Дарьин. - Пенза: РИО ПГСХА, 2015. - 166 с.

7. Кердяшов, Н. Н. Кормление сельскохозяйственных животных с использованием местных кормовых добавок: монография / Н. Н. Кердяшов. - Пенза: РИО ПГСХА. - 2007. - 177 с.

8. Кердяшов, Н. Н. Применение местных нетрадиционных кормовых добавок в промышленном животноводстве: монография / Н. Н. Кердяшов, А. И. Дарьин. - Пенза: РИО ПГСХА, 2016. $175 \mathrm{c}$.

9. Клейман, М. Б. Утилизация фрильтрационного осадка: проблемы и возможности / М. Б. Клейман // Сахарная промышленность. - 1995. - № 4. - С. 13-17.

10. Коков, Т. Н. Научные основы использования бентонитовых глин Северного Кавказа для оптимизации минерального питания крупного рогатого скота, свиней и птицы: автореферат диссертации на соискание ученой степени доктора сельскохозяйственных наук / Т. Н. Коков. - Владикавказ, 1998. - 46 с.

11. Миколайчик, М. Бентонит для животных и птицы / М. Миколайчик, С. Суханова, Ю. Кармацких // Комбикорма. - 2004. - № 4. - С. 48-49.

12. Молодцов, Г. П. Морской ил и дефекат сахарного производства в рационах откармливаемых свиней: вопросы интенсификации животноводства Дальнего Востока / Г. П. Молодцов, Т.И. Мельничук, Ю. П. Зелепукин // Сборник научных трудов Приморского СХИ. - Уссурийск, 1989. - С. 47-49.

13. Овсянников, А. И. Основы опытного дела в животноводстве / А. И. Овсянников. - Москва: Колос, 1976. - 304 с.

14. Осадок фильтрационный. Министерство сельского хозяйства и продовольствия Российской Федерации. Технические условия. ТУ 9112-005-00008664-95. - Москва, 1995. - 15 с. 
15. Плохинский, Н. А. Руководство по биометрии для зоотехников / Н. А. Плохинский. - Москва: Колос, 1969. - 256 с.

16. Смольянова, А. П. Результаты применения комплексных кормовых добавок на основе местного минерального сырья в кормлении молодняка животных / А. П. Смольянова, Н. Н. Кердяшов // Вестник Алтайского ГАУ. - 2011. - № 5(79). - С. 68-73.

17. Тишков, А. Н. Дефекат - источник кальция / А. Н. Тишков, М. В. Аргунов // Птицеводство. 1986. - № 2. - C. 11-13.

18. Kessel, W.-Cv. Die Zuckerrube - auch noch eine Futterpflanze / W. -Cv. Kessel // Zuckerrube. 1989. - V. 38. - № 5. - P. 268-272.

19. Mokolobate, M. S. Increases in $\mathrm{pH}$ and soluble salts influence the effect that additions of organic residues have on concentrations of exchangeable and soil solution aluminium / M. S. Mokolobate, R. J. Haynes // Europ. J. Soil Sc. - 2002. - V. 53. - № 3. - P. 481-489.

20. Przybyl, A. Proba wykorzystania surowcow odpadowych i ubocznych przemyslu rolno-spozywczego w granulatach karpiowych / A. Przybyl, M. Madziar, S. Blazkowiak // Roczn. Akad. Roln. w Poznaniu. Poznaniu. - 1993. - № 243. - P. 105-115.

21. Prufer, S. Empfehlungen zur Produktion und zum Einsatz von eiweissreichem Trockengrunfutter in der Schweinefutterung / S. Prufer // Tierzucht. - 1989. - V. 43. - № 3. - P. 134-135.

UDC 636. 087.7+636.2.084.1

DOI 10.36461/NP.2020.54.1.017

\title{
THE EFFECTIVENESS OF USING A FEED ADDITIVE BASED ON SUGAR PRODUCTION LIME IN FEEDING CALVES IN THE WINTER GROWING PERIOD
}

\author{
N. N. Kerdyashov, Doctor of Biological Sciences, Professor; \\ A. I. Dariin, Doctor of Agricultural Sciences, Professor
}

Federal State Budgetary Educational Institution of Higher Education «Penza State Agrarian University», Pussia, Penza, t. 8-9061589996, e-mail: nikolai1302@mail.ru

\section{A. V. Ovchinnikov, Doctor of Agricultural Sciences, Professor}

Federal State Budgetary Educational Institution of Higher Education «Russian State Agrarian University - Moscow Timiryazev Agricultural Academy», Moscow, Russia

The Volga region belongs to the biogeochemical provinces that are deficient in phosphorus, sulfur, sodium, zinc, iodine, cuprum, and cobalt. Sugar production lime contains calcium, phosphorus, and a number of other valuable nutrients. The use of sugar lime and feed additives based on it instead of fodder chalk helps to preserve the environment from contamination by waste from sugar production. One kilogram of the new feed additive made of the sugar production lime, vanillin and vitamin $D$ preparation contained: calcium - $285 \mathrm{~g}$, phosphorus $-12.5 \mathrm{~g}$, crude protein $-61.5 \mathrm{~g}$, sugar $-25 \mathrm{~g}$, ferrum $-3.9 \mathrm{~g}$, cuprum $-4.2 \mathrm{mg}$, manganese $-86.3 \mathrm{mg}$, zinc $-7.9 \mathrm{mg}$, cobalt $-0.11 \mathrm{mg}$, vitamin D - $55000 \mathrm{IU}$. The calves' eatability of the new feed additive is 31.6-61.1\% higher compared to the fodder chalk. The inclusion of this feed additive in the calves' diets ad libitum (without premixes) in the winter growing period significantly improves the basic zootechnical indicators of young animals in comparison with the use of fodder chalk: live weight - by 3.1-3.8 \%, the average daily increase in live weight - by $10.3-15.4 \%$, the absolute increase in live weight - by 10.3-15.2\%; the amount of feed item per $1 \mathrm{~kg}$ of the increase in live weight of calves lower than control by $9.4-13.2 \%$. The use of the studied feed additive is costeffective, since the cost of $1 \mathrm{~kg}$ of live weight increase of calves is lower by 18.81-19.33 rubles.

Keywords: sugar production lime, vanillin, vitamin D preparation, fodder chalk, calves, zootechnical indicators.

\section{References:}

1. Gutkovich, Ya. L. Productivity and metabolic processes of animals at different levels of microelementary nutrition / Ya. L. Gutkovich // Feed and feeding of farm animals. - 1991. - No. 4. - p. 4.

2. Dariin, A. I. Use of Echinacea Purpurea in feeding crossbred swine / A. I. Dariin. - Penza: Editorial and Publishing Unit of the Penza State Agrarian University. - 2009. - p. 65.

3. Egorecheva, O. N. The effectiveness of the use of filter sediment of sugar production and extruded soybeans in diets of the broiler chicken: abstract of the dissertation for the degree of Candidate of Agricultural Sciences. - Kursk, 2002. - p. 20.

4. Kalashnikov, A. P. Norms and diets of feeding farm animals: reference guide / A. P. Kalashnikov, V. I. Fisenin, V. V. Shcheglov et al. - Moscow: Agropromizdat, 2003. - p. 456.

5. Karunskij, A. I. Waste of sugar beet production in feeding swine and poultry / A. I. Karunskij, E. F. Kryuchkova, N. I. Nikilburskij // Zootechnics. - 1993. - No. 9. - p. 15-18. 
6. Kerdyashov, N. N. Feeding young animals with the use of complex feed additives: monograph / N. N. Kerdyashov, A. I. Dariin. - Penza: Editorial and Publishing Unit of the Penza State Agrarian University, 2015. - p. 166.

7. Kerdyashov, N. N. Farm animal feeding with local feed additives: monograph / N. N. Kerdyashov, A. I. - Penza: Editorial and Publishing Unit of the Penza State Agrarian University. - 2007. - p. 177.

8. Kerdyashov, N. N. The use of local non-traditional feed additives in industrial husbandry: monograph / N. N. Kerdyashov, A. I. Dariin. - Penza: Editorial and Publishing Unit of the Penza State Agrarian University, 2016. - p. 175.

9. Kleiman, M. B. Utilization of filtration sludge: problems and opportunities / M. B. Kleiman // Sugar industry. - 1995. - No. 4. - p. 13-17.

10. Kokov, T. N. Scientific bases of using bentonite clays of the North Caucasus for optimization of mineral nutrition of cattle, swine and poultry: abstract of the dissertation for the degree of Candidate of Agricultural Sciences / T. N. Kokov. - Vladikavkaz, 1998. - p. 46.

11. Mikolajchik, M. Bentonite for animal and poultry / M. Mikolajchik, S. Sukhanova, Yu. Karmatskikh // Kombikorma. - 2004. - No. 4. - p. 48-49.

12. Molodtsov, G. P. Marine clay and sugar production lime in the diets of fattening swine: issues of intensification of animal husbandry in the Far East / G. P. Molodtsov, T. I. Melnichuk, Yu. P. Zelepukin // Collection of scientific works of the Primorskaya State Academy of Agriculture. - Ussuriysk, 1989. p. 47-49.

13. Ovsyannikov, A. I. Fundamentals of experimental work in animal husbandry / A. I. Ovsyannikov. Moscow: Kolos, 1976. - p. 304.

14. Filter sediment. The Russian Federation Ministry of Agriculture Technical specifications. TS 9112-005-00008664-95. - Moscow, 1995. - p. 15.

15. Plokhinskij, N. A. Guide for biometrics for zootechnicians / N. A. Plokhinskij. - Moscow: Kolos, 1969. - p. 256.

16. Smoliyanova, A. P. Results of the application of complex feed additives based on local mineral raw materials in the feeding of young animals / A. P. Smolyanova, N. N. Kerdyashov // Bulletin of Altai State Agricultural University. - 2011. - No. 5 (79). - p. 68-73.

17. Tishkov, A. N. Defecate - a source of calcium / A. N. Tishkov, M. V. Argunov // Poultry Farming. 1986. - No. 2. - p. 11-13.

18. Kessel, W.-Cv. Die Zuckerrube - auch noch eine Futterpflanze / W. -Cv. Kessel // Zuckerrube. 1989. - V. 38. - № 5. - P. 268-272.

19. Mokolobate, M. S. Increases in $\mathrm{pH}$ and soluble salts influence the effect that additions of organic residues have on concentrations of exchangeable and soil solution aluminium / M. S. Mokolobate, R. J. Haynes // Europ. J. Soil Sc. - 2002. - V. 53. - № 3. - P. 481-489.

20. Przybyl, A. Proba wykorzystania surowcow odpadowych i ubocznych przemyslu rolno-spozywczego w granulatach karpiowych / A. Przybyl, M. Madziar, S. Blazkowiak // Roczn. Akad. Roln. w Poznaniu. Poznaniu. - 1993. - № 243. - P. 105-115.

21. Prufer, S. Empfehlungen zur Produktion und zum Einsatz von eiweissreichem Trockengrunfutter in der Schweinefutterung / S. Prufer // Tierzucht. - 1989. - V. 43. - № 3. - P. 134-135. 